\title{
Cerebrospinal fluid vasopressin in neurological and psychiatric disorders
}

\author{
PER SOELBERG SøRENSEN, ${ }^{*}$ ANNETTE GJERRIS, $\dagger$ MOGENS HAMMER \\ From the University Departments of Neurology, ${ }^{*}$ Neurosurgery, ${ }^{*}$ Psychiatry, $\dagger$ and Medicine $P, \ddagger$ \\ Rigshospitalet, Copenhagen, Denmark
}

SUMMARY Vasopressin was determined in CSF and plasma of 243 patients with different neurological and psychiatric disorders, including control patients. CSF vasopressin was significantly higher in patients with high pressure hydrocephalus, intracranial tumour, benign intracranial hypertension, intracranial haemorrhage, ischaemic stroke, and craniocerebral trauma. In patients with primary degenerative dementia, CSF vasopressin was lower than in control patients. Among patients with psychiatric disorders, CSF vasopressin was increased in manic patients, while in patients with depression CSF concentration of this hormone did not differ from that found in controls. However, an increase in CSF vasopressin level was found in patients recovering from a depression. The clinical significance of changes in CSF vasopressin concentrations in groups of patients with neurological and psychiatric disorders is still unknown.

The neurohypophyseal hormone arginine vasopressin (AVP) has been demonstrated in various extrahypothalamic locations within the central nervous sytem ${ }^{1-5}$ and AVP is found in the cerebrospinal fluid (CSF) of normally hydrated subjects in concentrations similar to or lower than the corresponding plasma concentrations. ${ }^{6-8}$ However, in a number of neurological disorders a diverging ratio of $\mathrm{CSF} /$ plasma concentration has been found indicating a separate regulation of the release of AVP into the CSF. ${ }^{9-11}$

Several hypotheses on the function of AVP within the central nervous system have been offered. Vasopressin in the CSF has been suggested to have an effect on brain water permeability ${ }^{12}$ and on the intracranial pressure, ${ }^{13}$ and a direct relationship between the intracranial pressure and CSF AVP concentration has been proposed." from animal studies have suggested that AVP might influence learning and memory functions, and low CSF concentrations of AVP have been found in patients with dementia. ${ }^{1617}$ Gold et al. have proposed the hypothesis that AVP is implicated in changes of mood in manic-depressive illness. ${ }^{18}$

In the present study AVP concentrations in CSF Address for reprint requests: Per Soelberg Sorensen, M.D. University Department of Neurosurgery, Rigshospitalet, DK-2100 Copenhagen, Denmark.

Received 21 February 1984 and in revised form 7 June 1984. Accepted 11 June 1984. and plasma have been measured in an extended number of patients with dementia and intracranial hypertension, and we have included several other groups of patients with neurological and psychiatriog disorders and control patients with no signs of cen tral nervous system disease.

\section{Materials and methods}

\section{Control patients}

This group comprised 52 patients, 22 men and 30 women, aged 21-76 years, median age 46 years (table 1 ). Twentyeight patients had symptoms of a cervical or lumbar disc syndrome and were admitted for diagnostic myelography. Eleven patients had headache or common migraine. Seven patients had diffuse neurological symptoms as dizziness or paraesthesia, but no signs of organic disease were found. Six patients had minor peripheral neurological symptoms. No patients had signs indicating central nervous system lesions and no endocrine disorders were suspected. No medication was given at the time of examination. CSF and blood samples were taken between 8 and 11 am in connection with the myelography in patients with disc syndromes and at a diagnostic lumbar puncture in the other patients. All patients were fasting overnight and were kept supine for $30 \mathrm{~min}$ before the lumbar puncture which was performed using local anaesthesia and with the patients in the lateral recumbent position. The CSF pressure was measured before removal of CSF. All patients had normal CSF pressure, protein concentration, and cell count. Venous blood samples were obtained just before the lumbar puncture. Informed consent was obtained from all patients. 
Table 1 Age and sex distribution in groups of patients with neurological and psychiatric disorders and controls.

\begin{tabular}{|c|c|c|c|c|c|}
\hline Diagnosis & $N$ & $\begin{array}{l}\text { Age }(y r) \\
\text { Median }\end{array}$ & Range & $\begin{array}{l}\text { Sex } \\
\text { Male }\end{array}$ & Female \\
\hline $\begin{array}{l}\text { Normal pressure hydrocephalus } \\
\text { High pressure hydrocephalus } \\
\text { Intracranial tumour } \\
\text { Benign intracranial hypertension } \\
\text { Intracranial haemorrhage } \\
\text { Ischaemic stroke } \\
\text { Cranio-cerebral trauma } \\
\text { Multiple sclerosis } \\
\text { Basal ganglia disorders } \\
\text { Primary degenerative dementia } \\
\text { Endogenous depression } \\
\text { Non-endogenous depression } \\
\text { Mania } \\
\text { Schizophrenia } \\
\text { Controls }\end{array}$ & $\begin{array}{r}29 \\
6 \\
14 \\
18 \\
9 \\
10 \\
5 \\
8 \\
5 \\
25 \\
32 \\
14 \\
7 \\
9 \\
52\end{array}$ & $\begin{array}{l}65 \\
29 \\
47 \\
35 \\
52 \\
61 \\
52 \\
39 \\
42 \\
56 \\
46 \\
47 \\
34 \\
29 \\
46\end{array}$ & $\begin{array}{r}37-72 \\
2-62 \\
7-73 \\
13-53 \\
28-66 \\
42-70 \\
12-60 \\
15-59 \\
20-63 \\
30-71 \\
18-82 \\
22-66 \\
30-49 \\
19-40 \\
21-76\end{array}$ & $\begin{array}{r}19 \\
2 \\
9 \\
4 \\
2 \\
7 \\
3 \\
5 \\
2 \\
19 \\
16 \\
6 \\
1 \\
6 \\
22\end{array}$ & $\begin{array}{r}10 \\
4 \\
5 \\
14 \\
7 \\
3 \\
2 \\
3 \\
3 \\
6 \\
16 \\
8 \\
6 \\
3 \\
30\end{array}$ \\
\hline
\end{tabular}

Patients with diseases of the central nervous system All patients with neurological disorders were admitted to the Neurological og Neurosurgical Clinics, Rigshospitalet. Age and sex distribution in the different patient groups is given in table 1 . None of the patients received any medication and none had clinical signs of endocrine diseases. CSF and blood samples were taken using the same procedure as in the control patients. However, in two patients with high pressure hydrocephalus, in all patients with intracranial tumour or cranio-cerebral trauma, and in seven patients with intracranial haemorrhage ventricular CSF specimens were obtained due to the hazards of lumbar puncture in these patients.

Normal pressure hydrocephalus. Twenty nine patients had clinical symptoms of normal pressure hydrocephalus: dementia, gait disturbances, and/or urinary incontinence. All had ventricular enlargement in CT-scan, some with periventricular lucency. The intraventricular pressure was normal $(<12 \mathrm{~mm} \mathrm{Hg})$, and all had decreased conductance to CSF-outflow measured by a lumbar-ventricular perfusion study. ${ }^{19}$ In 17 patients lumbar and ventricular CSF samples were taken simultaneously in connection with the perfusion study.

High pressure hydrocephalus. Six patients had high pressure hydrocephalus: two had communicating high pressure hydrocephalus as a complication to subarachnoid haemorrhage, one as a complication to an ependymoma of the cauda equina, and one was suspected to have congenital stenosis of the aqueduct of Sylvius. The last two patients were children with congenital hydrocephalus and obstruction of a previously placed ventriculo-atrial shunt. In all patients the intraventricular pressure was increased $(\geqslant 18 \mathrm{~mm} \mathrm{Hg}$ ).

Intracranial tumour. Fourteen patients had intracranial tumours, including five acoustic neuromas, two cerebellar astrocytomas, one cerebellar haemangioblastoma, one fourth ventricle papilloma of the choroid plexus, two pinealomas, two cerebral gliomas, and one craniopharyngeoma. Seven of the patients had complicating obstructive hydrocephalus. Eleven patients had increased intraventricular pressure $(\geqslant 18 \mathrm{~mm} \mathrm{Hg})$.

Benign intracranial hypertension. This group comprised 18 patients fulfilling the following diagnostic criteria: raised intracranial pressure, papilloedema, normal or diminished ventricular size on CT. The intracranial pressure, measured by epidural pressure monitoring in 12 patients, and via a lumbar cannula in six patients, was increased $(\geqslant 18 \mathrm{~mm} \mathrm{Hg})$ in 13 of the 18 patients. All had low or normal CSF protein concentration.

Intracranial haemorrhage. This group comprised nine patients with either recent subarachnoid haemorrhage (six patients) or intracerebral haematoma (three patients). The intracranial pressure was measured by intraventricular pressure monitoring in seven patients and by lumbar puncture in two. Six patients had increased $(\geqslant 18 \mathrm{~mm} \mathrm{Hg})$ intracranial pressure.

Ischaemic stroke. Ten patients were examined during the week following an ischaemic stroke. The diagnosis was confirmed by CT which showed a lesion compatible with a cerebral infarct. The intracranial pressure was elevated $(\geqslant 18 \mathrm{~mm} \mathrm{Hg})$ in two patients. None of the patients had haemorrhagic CSF.

Cranio-cerebral trauma. This group comprised five patients, of whom three had cerebral contusion, one traumatic subarachnoid haemorrhage, and one epidural haematoma. The intraventricular pressure was increased $(\geqslant 18 \mathrm{~mm} \mathrm{Hg})$ in three patients.

Multiple sclerosis. Eight patients had multiple sclerosis diagnosed according to the criteria of Schumacher et al, ${ }^{20}$ and the diagnosis was confirmed by abnormalities in visual or somatosensory evoked potentials and/or signs of intrathecal IgG production. The lumbar CSF pressure was normal.

Miscellaneous basal ganglia disorders. The group comprised five patients, of whom two had Parkinson's disease, one Huntington's chorea, one torsion dystonia, and one Gilles de la Tourette syndrome. Normal lumbar CSF pressure was found in all patients.

Primary degenerative dementia. Twenty five patients with a history of progressive dementia were studied. The diagnosis primary degenerative dementia was made by history, neuropsychological examination, metabolic screening, and CT. None of the patients had symptoms of multi infarct dementia. All had normal CSF pressure measured by lum- 
bar puncture.

Patients with psychiatric disorders

The psychiatric patients were all admitted to the Department of Psychiatry, Rigshospitalet. All diagnoses and ratings were made by a psychiatrist who did not otherwise take part in the study. None of the patients had any known endocrine disease. In all groups of psychiatric patients, measurement of lumbar CSF pressure, collection of CSF and blood samples were performed following the same procedures as described in the control patients. Age and sex distribution in the different patient groups is shown in table 1.

Endogenous depression (melancholia). Thirty two patients were classified as endogenous depression according to the International Classification of Diseases, 8th Edition (ICD-8) (296). The patients were rated using the BechRafaelsen melancholia scale (BRMES) ${ }^{21}$ and all patients entering the study had a score above 15 . None of the patients received any mediation at the time of study except one patient who was treated with lithium carbonate. Twelve patients were reexamined after they had recovered from the depression, represented by a score below 7 in the BRMES. Two patients had been treated with electroconvulsive therapy, eight with antidepressant drugs, one with antidepressant drugs and lithium carbonate, and one with lithium carbonate alone.

Non-endogenous depression. This group consisted of 14 patients, including the ICD-8 diagnoses 298 (reactive depression), 299 (other psychotic depression), 300 (depressive neurosis), and 301 (cyclothymic personality). None of the patients received any medication.

Mania. Seven patients with manic-depressive psychosis (ICD-8: 296) were examined in a manic phase, all having a score above 10 on the Bech-Rafaelsen mania scale (BRMS).22 All were without any medication when studied. Schizophrenia. Nine patients diagnosed as schizophrenic according to ICD-8 (295) were included. This group comprised both acute and chronic schizophenic patients. At the time of examination none of the patients received any medication.

\section{Analytical methods}

CSF and blood for AVP analyses were sampled in chilled tubes and placed on ice. The blood samples were taken in plastic tubes containing $8 \mathrm{mg} \mathrm{Na}_{2}$-EDTA and separated immediately. Blood for osmolality measurements was collected in heparinised tubes. Plasma and CSF samples were stored at $-20^{\circ} \mathrm{C}$ until analyses. CSF and plasma AVP concentrations were determined by radioimmunoassay after extraction of $2 \mathrm{ml}$ samples in duplicate with acetone and petroleum ether as previously described. ${ }^{23}$ The sensitivity of the analysis was $0.5 \mathrm{pg} / \mathrm{ml}$ and the intra- and inter-assay coefficient of variation were $5-10 \%$ and $15 \%$, respectively. In studies using gelfiltration of the extracted CSF and plasma samples, the immunoreactivity was recovered in the same fraction as the synthetic AVP standard (Ferring, Sweden). Plasma and CSF osmolality were determined by freezing point depression (Knauer automated digital osmometer), coefficient of variation was less than $1 \%$.

Statistical analyses were performed using analysis of variance and Student's $t$ test for paired data. As hormone values in some of the patient groups could not be assumed to be normally distributed, Kruskal-Wallis test was employed. Significance levels: $\alpha=0.05,0.01$ and 0.001 .

\section{Results}

\section{Control patients}

CSF and plasma AVP concentration and osmolality are shown in table 2 and 3 and fig. Mean CSF AVP concentration was $1.3 \pm 0 \cdot 1 \mathrm{pg} / \mathrm{ml}(\mathrm{SEM})$, and no difference was found between men $(1.4 \pm 0.1 \mathrm{pg} / \mathrm{ml}$ (SEM) and women $(1.3 \pm 0.1 \mathrm{pg} / \mathrm{ml}(\mathrm{SEM})$. No statistical correlation was found between age and CSF AVP concentration $(r=-0 \cdot 01)$. Plasma AVP was higher than CSF AVP in all patients but three, but no statistical correlation was found between plasma and CSF vasopressin concentrations $(r=$ $0 \cdot 22 ; p>0 \cdot 1)$. Plasma and CSF osmolalities were

Table 2 Vasopressin concentration and osmolality in CSF and plasma in groups of patients with different neurological disorders and in controls (Means $\pm S E M$ ).

\begin{tabular}{|c|c|c|c|c|c|}
\hline Dia & $N$ & \multicolumn{2}{|c|}{$\begin{array}{l}\text { Vasopressin conc. }(\mathrm{pg} / \mathrm{ml}) \\
\text { CSF }\end{array}$} & \multicolumn{2}{|c|}{ Osmolality (mosm/kg $\left.\mathrm{H}_{2} \mathrm{O}\right)$} \\
\hline $\begin{array}{l}\text { Normal pressure hydrocephalus } \\
\text { High pressure hydrocephalus } \\
\text { Intracranial tumour } \\
\text { Benign intracranial hypertension } \\
\text { Intracranial haemorrhage } \\
\text { Ischaemic stroke } \\
\text { Cranio-cerebral trauma } \\
\text { Multiple sclerosis } \\
\text { Basal ganglia disorders } \\
\text { Primary degenerative dementia } \\
\text { Controls }\end{array}$ & $\begin{array}{r}29 \\
6 \\
14 \\
18 \\
9 \\
10 \\
5 \\
8 \\
5 \\
25 \\
52\end{array}$ & $\begin{array}{l}1 \cdot 3 \pm 0.1 \\
2.4 \pm 0.5 \ddagger \\
2 \cdot 5 \pm 0.3 \ddagger \\
1.9 \pm 0.2 \ddagger \\
1.9 \pm 0.3^{*} \\
1 \cdot 8 \pm 0.3^{*} \\
2 \cdot 0 \pm 0.3 \dagger \\
1 \cdot 5 \pm 0.1 \\
1 \cdot 3 \pm 0.2 \\
0.9 \pm 0.1 \ddagger \\
1.3 \pm 0.1\end{array}$ & $\begin{array}{l}3 \cdot 5 \pm 0.4 \\
2 \cdot 9 \pm 0.8 \\
4 \cdot 9 \pm 1 \cdot 1 \dagger \\
2 \cdot 8 \pm 0 \cdot 4 \\
5 \cdot 0 \pm 1 \cdot 1 \dagger \\
2 \cdot 7 \pm 0.8 \\
3 \cdot 4 \pm 1 \cdot 0 \\
3 \cdot 0 \pm 0 \cdot 4 \\
2 \cdot 0 \pm 0.3^{*} \\
1 \cdot 8 \pm 0 \cdot 2 \dagger \dagger \\
3 \cdot 1 \pm 0.2\end{array}$ & $\begin{array}{l}283 \pm 1 \\
281 \pm 4 \\
287 \pm 3 \\
285 \pm 2 \\
274 \pm 10 \\
291 \pm 4^{*} \\
272 \pm 12 \ddagger \\
284 \pm 3 \\
283 \pm 3 \\
284 \pm 1 \\
283 \pm 1\end{array}$ & $\begin{array}{l}284 \pm 1 \\
279 \pm 4 \\
285 \pm 2 \\
284 \pm 2 \\
280 \pm 8 \\
288 \pm 2 \\
269 \pm 10 \mp \\
285 \pm 3 \\
284 \pm 2 \\
286 \pm 1 \\
286 \pm 1\end{array}$ \\
\hline
\end{tabular}

${ }^{*} \mathrm{p}<0.05$ compared with controls.

$\dagger p<0.01$ compared with controls.

$\ddagger \mathrm{p}<0.001$ compared with controls. 
Table 3 Vasopressin concentration and osmolality in CSF and plasma in groups of patients with different psychiatric disorders and in controls (Means \pm SEM).

\begin{tabular}{|c|c|c|c|c|c|}
\hline Diagnosis & $\boldsymbol{N}$ & $\begin{array}{l}\text { Vasopressin } \\
\text { CSF }\end{array}$ & $\begin{array}{l}\text { (pg/ml) } \\
\text { Plasma }\end{array}$ & $\begin{array}{l}\text { Osmolalit } \\
\text { CSF }\end{array}$ & $\begin{array}{l}\left.\text { (kg } \mathrm{H}_{2} \mathrm{O}\right) \\
\text { Plasma }\end{array}$ \\
\hline $\begin{array}{l}\text { Endogenous depression } \\
\text { Non-endogenous depression } \\
\text { Mania } \\
\text { Schizophrenia } \\
\text { Controls }\end{array}$ & $\begin{array}{r}32 \\
14 \\
7 \\
9 \\
52\end{array}$ & $\begin{array}{l}1 \cdot 3 \pm 0 \cdot 1 \\
1 \cdot 2 \pm 0 \cdot 1 \\
1 \cdot 9 \pm 0 \cdot 3 * \\
1 \cdot 5 \pm 0 \cdot 1 \\
1 \cdot 3 \pm 0 \cdot 1\end{array}$ & $\begin{array}{l}2.6 \pm 0.3 \\
2.4 \pm 0.3 \\
2.6 \pm 0.5 \\
2.6 \pm 0.4 \\
3.1 \pm 0.2\end{array}$ & $\begin{array}{l}284 \pm 1 \\
284 \pm 2 \\
282 \pm 1 \\
283 \pm 2 \\
283 \pm 1\end{array}$ & $\begin{array}{l}288 \pm 1 \\
288 \pm 2 \\
286 \pm 3 \\
287 \pm 2 \\
286 \pm 1\end{array}$ \\
\hline
\end{tabular}

$* \mathrm{p}<\mathbf{0 . 0 1}$ compared with controls.

not significantly different, and a significant correlation was found between plasma osmolality and plasma AVP concentration $(r=0.46 ; p<0.001)$.

Patients with diseases of the central nervous system CSF and plasma AVP concentrations and osmolalities are shown in table 2 and fig. Mean CSF AVP concentration was higher in patients with high pressure hydrocephalus, intracranial tumour, benign intercranial hypertension, intracranial haemorrhage, ischaemic stroke, and cranio-cerebral traume, that is in all groups of patients where raised intracranial pressure frequently was observed. In patients with multiple sclerosis and basal ganglia disorders mean CSF AVP was not different from the value found in the control patients. However, low values of CSF AVP were found in two patients with Parkinson's disease $(0.8$ and $1.0 \mathrm{pg} / \mathrm{ml})$. Patients with primary degenerative dementia had significantly reduced CSF AVP concentration ( $0.9 \pm 0.1 \mathrm{pg} / \mathrm{ml}$ (SEM)) compared with controls. No significant difference was found between simultaneously sampled lumbar $(1.4 \pm 0.1 \mathrm{pg} / \mathrm{ml}(\mathrm{SEM}))$ and ventricular (1.5 \pm $0 \cdot 1 \mathrm{pg} / \mathrm{ml}($ SEM)) CSF from 17 patients with normal pressure hydrocephalus.

Mean plasma AVP concentration was increased in patients with intracranial tumour and intracranial haemorrhage and decreased in patients with basal ganglia disorder and primary degenerative dementia when compared with mean plasma AVP in the control patients. No relationship was found between CSF and plasma AVP values in any of the patient groups, except in patients with benign intracranial hypertension $(r=0.65 ; p<0.01)$.

Mean plasma and CSF osmolalities did not differ from the values found in controls except in the group of patients with cranio-cerebral trauma. Two patients with cranial trauma, two with intracranial tumour and one with subarachnoid haemorrhage had symptoms of inappropriate secretion of antidiuretic hormone syndrome with severe hypoosmolality $(<260 \mathrm{mosm} / \mathrm{kg})$ and hyponatraemia and normal or even high plasma AVP concentrations. The relationship between plasma osmolality and plasma
AVP, which was demonstrated in the control patients, was not present in any group of patients with intracranial disorders, and several patients showed plasma AVP concentrations which in relation to the corresponding plasma osmolalities were outside the range found in normal subjects. ${ }^{24}$

\section{Patients with psychiatric disorders}

CSF and plasma AVP concentrations and osmolalities are given in table 3 and fig. Mean CSF AVP concentration was higher in manic patients while depressive and schizophrenic patients had values similar to that found in control patients. However, in 12 endogenous depressive patients who were examined during depression and reexamined after recovery, CSF AVP was lower in the state of depression $(1.2 \pm 0.1 \mathrm{pg} / \mathrm{ml}(\mathrm{SEM}))$ than after recovery $(1.5 \pm 0.1 \mathrm{pg} / \mathrm{ml}(\mathrm{SEM}) ; \mathrm{p}<0.05)$.

Mean plasma AVP was not different from that found in control patients in any group of psychiatric patients. In patients with endogenous depression and in patients with mania plasma AVP and CSF AVP concentrations were significantly correlated ( $r$ $=0.47$ and $r=0.82$, respectively; $\mathrm{p}<0.01$ ), whereas such a correlation was not seen in the control patients.

Plasma and CSF osmolalities were within the normal range (table 3), but a relationship between plasma osmolality and plasma AVP, as found in the controls, could not be demonstrated in any group of psychiatric patients.

\section{Discussion}

The concentration of AVP in CSF was increased in those intracranial disorders that commonly cause raised intracranial pressure. This is consistent with previous findings of a direct relationship between the intracranial pressure and CSF AVP concentration in a smaller series of patients with intracranial hypertension. " Some of the neurological conditions are characterised by damage of brain tissue and possible breakdown of the blood-CSF barrier, which could contribute to the raised CSF AVP concentra- 


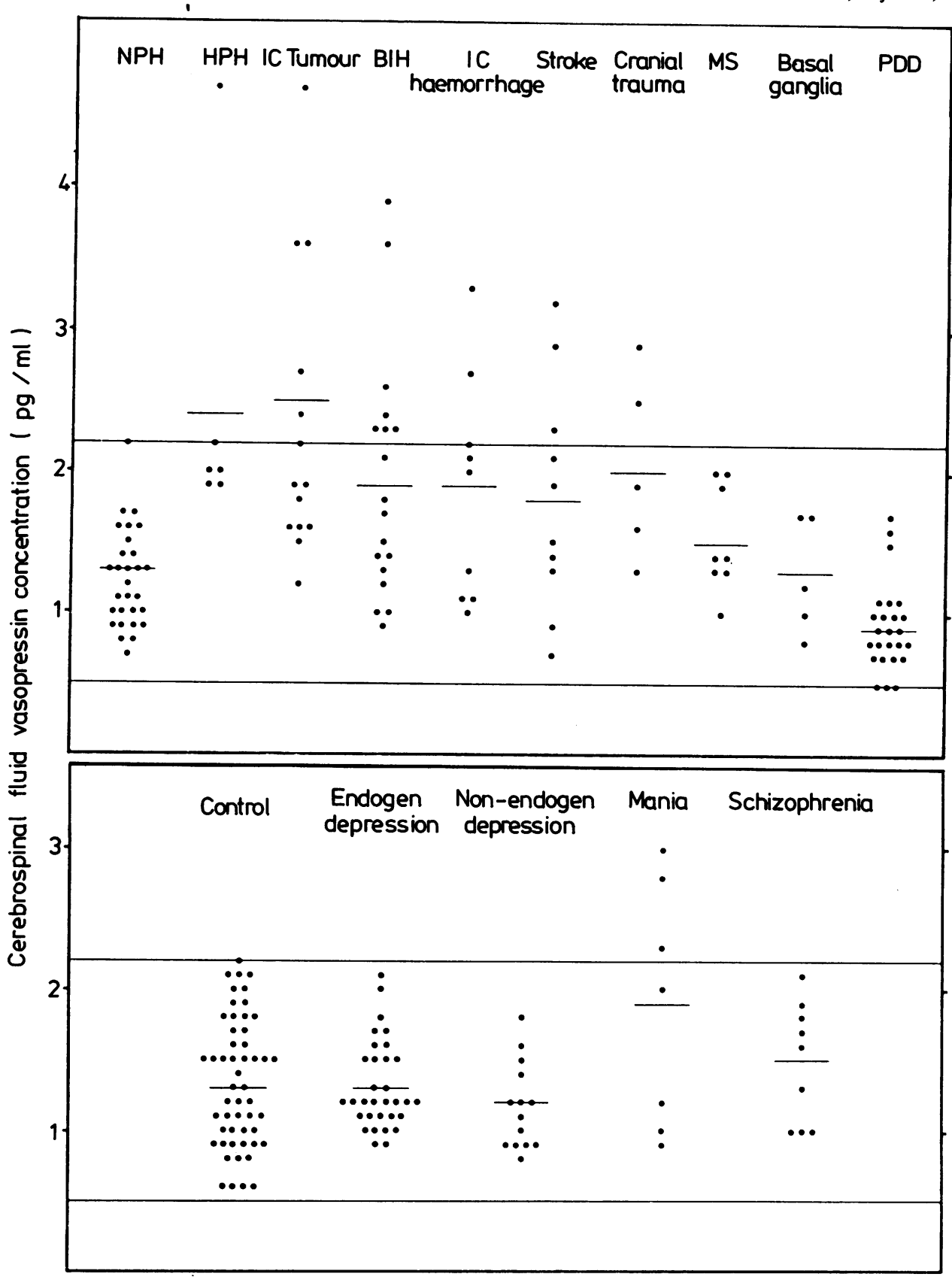

Fig Cerebrospinal fuid vasopressin in patients with different neurological diseases (upper panel) and in patients with different psychiatric disorders and control patients (lower panel). The area between solid lines indicates the 95\% confidence interval for controls. (NPH: normal pressure hydrocephalus; HPH: high pressure hydrocephalus; IC.: intracranial; BIH: benign intracranial hypertension; MS: multiple sclerosis; basal ganglia: Miscellaneous basal ganglia disorders; PDD: primary degenerative dementia; Endogen.: endogenous) 
tion. However, high CSF AVP concentrations were also found in patients with benign intracranial pressure with no signs of abnormal blood-CSF barrier function. Hence, the raised intracranial pressure probably is a contributory cause of the increase in CSF AVP. In patients with multiple sclerosis and basal ganglia disorders, in whom a normal intracranial pressure was measured, no changes in CSF AVP were found. Our findings are in accordance with previous observations of increased CSF AVP in sporadic cases of intracranial tumor, ${ }^{7}$ subarachnoid haemorrhage, ${ }^{9}$ meningitis, ${ }^{25}$ and cerebrovascular disease. ${ }^{17}$ Sørensen et $a^{10}$ found CSF AVP increased in patients with benign intracranial hypertension when compared with controls, and the same observation was made by Reid and Morton ${ }^{26}$ who, however, found CSF AVP equally increased in other neurological patients with normal intracranial pressure. The increased AVP concentrations in CSF, found in various neurological disorders with raised intracranial pressure, is unlikely to be the cause of the intracranial hypertension. However, animal experiments have implicated CSF AVP in brain water permeability ${ }^{12}$ and brain water accumulation, ${ }^{27}$ and if inference can be made from these studies it is possible that increased concentrations of AVP in the CSF might be an additional harmful factor in patients with increased intracranial pressure. It might be argued that comparison of AVP concentrations in ventricular and lumbar CSF is involved. In the present study simultaneously sampled CSF from the ventricular system and the lumbar cistern in the patients with normal pressure hydrocephalus did not disclose any rostro-caudal gradient for the hormone. However, a certain caution must be exercised when comparing AVP concentrations in CSF obtained from different levels within the neuroaxis in these patients with abnormal CSF dynamics. In a previous study ${ }^{8}$ we found no changes in the AVP concentration in three consecutive $5 \mathrm{ml}$ fractions of CSF drained from the lumbar cistern of control patients with assumed normal CSF dynamics.

The present study has confirmed previous findings of decreased CSF AVP in patients with organic dementia. ${ }^{1617}$ A single study, however, reported increased CSF AVP levels in senile dementia, but was unable to detect AVP in CSF of control patients. ${ }^{28}$ Low levels of AVP in CSF was found in a small number of patients with dementia caused by aicholism. ${ }^{29}$ The findings of low CSF AVP levels in dementia would be consistent with findings of low AVP contents in brains of demented patients. Rossor et al, ${ }^{30}$ however, found only insignificantly decreased AVP content in brains of patients with Alzheimer dementia, whereas Mann et al ${ }^{31}$ found signs of reduced protein synthetic capacity in cells of the supraoptic and paraventricular nuclei in patients with Alzheimer disease. It should be emphasised, however, that a certain caution must be exercised in drawing conclusions regarding the implication of AVP in memory processes from findings of low AVP concentrations in CSF. Other neuropeptides ${ }^{32}$ and enzyme systems ${ }^{30}$ have been found reduced in Alzheimer disease, and the reduction of neuropeptides including AVP might only be an epiphenomenon to the diffuse loss of cells within the central nervous system. A number of therapeutic trials have been conducted using intranasally administered AVP and synthetic analogues for treatment of memory disturbances of various kind. ${ }^{33-39}$ The results of these trials have been conflicting, but regarding the controlled studies mainly negative. The inability of AVP and synthetic analogues to pass the blood-CSF barrier ${ }^{4041}$ might be the main cause for the negative results in trials using intranasally drug administration.

In the present study, the AVP concentration in CSF of endogenously depressed patients was not different from that found in controls, whereas CSF AVP was increased in manic patients. Thus, the result of the present study is not inconsistent with the findings of Gold $e a^{4243}$ that CSF AVP is decreased in the depressed state of affective illness and increased in mania, as we observed an increase in CSF AVP concentration in patients who recovered from a depression. In a previous study we have shown that treatment of depressed patients with electroconvulsive therapy evokes a marked but transient increase in plasma AVP concentration, and a trend toward a moderate rise in basal plasma AVP levels was found in patients who responded satisfactorily to electroconvulsive therapy. ${ }^{44}$

The present study has demonstrated that significant alterations in CSF AVP levels can be found in various neurological and psychiatric diseases. However, the clinical significance of changes in CSF AVP levels is still obscure and further studies are needed on this subject.

This study was supported by grants from the Danish Medical Research Council.

\section{References}

' Brownfield MS, Kozlowski GP. The hyothalamochoroidal tract. I. Immunohistochemical demonstration of neurophysin pathways to telencephalic choroid plexuses and cerebrospinal fluid. Cell Tissue Res 1977; 178: 111-27.

${ }^{2}$ Buijs RM, Swaab DF, Dogterom J, van Leeuwen FW. Intra- and extrahypothalamic vasopressin and oxyto- 
cin pathways in the rat. Cell Tissue Res 1978; 186:423-33.

${ }^{3}$ Weindl A, Sofroniew MV. Immunohistochemical localization of hypothalamic peptide hormones in the neural target areas. In: Wuttke A, Weindl A, Voight KH, Dries RR, eds. Brain and Pituitary Peptides. Basel: Karger, 1980:97-109.

4 Hawthorn J, Ang VTY, Jenkins JS. Localization of vasopressin in the rat brain. Brain Res 1980;197:75-81.

5 Rossor MN, Iversen LL, Hawthorn J, Ang VTY, Jenkins JS. Extrahypothalamic vasopressin in human brain. Brain Res 1981;214:349-55.

- Luerssen TG, Robertson GL. Cerebrospinal fluid vasopressin and vasotocin in health and disease. In: Wood JH, ed. Neurobiology of Cerebrospinal Fluid. New York: Plenum Press 1980:613-23.

7 Jenkins JS, Mather HM, Ang V. Vasopressin in human cerebrospinal fluid. J Clin Endocrin Metab 1980;50:364-7.

${ }^{8}$ Hammer M, Sørensen PS, Gjerris F, Larsen K. Vasopressin in the cerebrospinal fluid of patients with normal pressure hydrocephalus and benign intracranial hypertension. Acta Endocrinol 1982;100:211-5.

9 Mather HM, Ang V, Jenkins JS. Vasopressin in plasma and CSF of patients with subarachnoid haemorrhage. J Neurol Neurosurg Psychiatry 1981;44:216-9.

${ }^{10}$ Sørensen PS, Hammer M, Gjerris F. Cerebrospinal fluid vasopressin in benign intracranial hypertension. Neurology (Ny) 1982;32:1255-9.

" Sørensen PS, Gjerris F, Hammer M. Cerebrospinal fluid vasopressin and increased intracranial pressure. Ann Neurol 1984;15:435-40.

12 Raichle ME, Grubb RL. Regulation of brain water permeability by centrally-released vasopressin. Brain Res 1978; 143: 191-4.

${ }^{13}$ Noto T, Nakajima T, Saji Y, Nagawa Y. Effect of vasopressin on intracranial pressure of rabbit. Endocrinol Japon 1978;25:591-6.

$14 \mathrm{De}$ Wied $\mathrm{D}$. The influence of the posterior and intermediate lobe of the pituitary and pituitary peptides on the maintenance of a conditioned avoidance response in rats. Int $J$ Neuropharmacol 1965;4:157-67.

is De Wied D, van Wimersma Greidanus TB, Bohus B, Urban I, Gispen WH. Vasopressin and memory consolidation. In: Corner MA, Swaab DF, eds. Perspectives in Brain Research. Progress in Brain Research. Amsterdam Elsevier. 1976:181-94.

16 Sørensen PS, Hammer M, Vostrup S, Gjerris F. CSF and plasma vasopressin concentrations in dementia. $J$ Neurol Neurosurg Psychiatry 1983;46:911-16.

17 Sundquist J, Forsling ML, Olsson JE, Åkerlund M. Cerebrospinal fluid arginine vasopressin in degenerative disorders and other neurological diseases. $J$ Neurol Neurosurg Psychiatry 1983;46:14-7.

${ }^{18}$ Gold PW, Goodwin FK, Reus VI. Vasopressin in affective illness. Lancet 1978;1:1233-6.

19 Børgesen SE, Gjerris F, Sørensen SC. The resistance to cerebrospinal fluid absorption in humans. Acta Neurol Scand 1978;57:88-96.

${ }^{20}$ Schumacher GA, Beebe G, Kibler RF, et al. Problems of experimental trials of therapy in multiple sclerosis: report by the panel on the evaluation of experimental trials of therapy of multiple sclerosis. Ann N Y Acad Sci 1965;122:552-68.

${ }^{21}$ Bech P, Rafaelsen OJ. The use of rating scales exemplified by a comparison of the Hamilton and the Bech-Rafaelsen Melancholia Scale. Acta Psychiat Scand 1980;62 (suppl. 285): 128-32.

22 Bech P, Bolwig TG, Kramp P, Rafaelsen OJ. The Bech-Rafaelsen Mania Scale and the Hamilton Depression Scale. Acta Psychiat Scand 1979;59:420-30.

${ }^{23}$ Hammer M. Radioimmunoassay of 8arginine-vasopressin (antidiuretic hormone) in human plasma. Scand J Clin Lab Invest 1978;38:707-16.

${ }^{24}$ Hammer M, Ladefoged J, Ølgaard K. Relationship between plasma osmolality and plasma vasopressin in human subjects. Am J Physiol 1979;238:E313-7.

${ }^{25}$ Garcia H, Kaplan SL, Feigin RD. Cerebrospinal fluid concentration of arginine vasopressin in children with bacterial meningitis. J Pediatr 1981;98:67-70.

${ }^{26}$ Reid AC, Morton JJ. Arginine vasopressin levels in cerebrospinal fluid in neurological disease. $J$ Neurol Sci 1982;54:295-301.

${ }^{27}$ Doczi T, Szerdahelyi P, Gulya K, Kiss J, Brain water accumulation after the central administration of vasopressin. Neurosurgery 1982;11:402-7.

${ }^{28}$ Tsuji M, Takahashi S, Akazawa S. CSF vasopressin and cyclic nucleotide concentrations in senile dementia Psychoneuroendocrinology 1981;6:171-6.

${ }^{29}$ Noto T, Kato N, Inoue K, Kitabayashi M, Nakajima T. The levels of vasopressin in cerebrospinal fluid of patients with alcoholism. Endocrinol Japon 1982; 29: 121-4.

${ }^{30}$ Rossor MN, Fersen LL, Mountjoy CQ, et al. Arginine vasopressin and choline acetyltransferase in brains of patients with Alzheimer type senile dementia. Lancet 1980;2:1367-8.

${ }^{31}$ Mann DMA, Yates PO, Bansal DV, Marshall DJ. Hypothalamus and dementia. Lancet 1981;1:393-4.

${ }^{32}$ Oram JJ, Edwardson J, Millard PH. Investigation of cerebrospinal fluid neuropeptides in idiopathic senile dementia. Gerontology 1981;27:216-23.

${ }^{33}$ Legros JJ, Gilot P, Seron X, et al. Influence of vasopressin on learning and memory. Lancet 1978;1:41-2.

${ }^{34}$ Weingartner H, Gold P, Ballenger JC, et al. Effects of vasopressin on human memory functions. Science 1981;211:601-3.

${ }^{35}$ Jenkins JS, Mather HM, Coughlan AK, Jenkins GD. Desmopressin and desglycinamide vasopressin in post-traumatic amnesia. Lancet 1981;1:39.

36 Weingartner $\mathrm{H}$, Kaye W, Gold $\mathrm{P}$, et al. Vasopressin treatment of cognitive dysfunction in progressive dementia. Life Sci 1981;29:2721-6.

${ }^{37}$ Durso R, Fedio F, Brouwers P, et al. Lysine vasopressin in Alzheimer disease. Neurology (Ny) 1982;32: 674-7.

${ }^{38}$ Reichert WH, Blass JP. A placebo-controlled trial shows no effect of vasopressin on recovery from closed head injury. Ann Neurol 1982;12:390-2.

${ }^{39}$ Francheshi M, Tancredi O, Savio G, Smirne S. Vasopressin and physostigmine in the treatment of amnesia. Eur Neurol 1982;21:388-91.

${ }^{40}$ Ang VTY, Jenkins JS. Blood-cerebrospinal fluid barrier 
to arginine-vasopressin, desmopressin and desglycinamide arginine-vasopressin in the dog. $J$ Endocrinol 1982;93:319-25.

4 ' Sørensen PS, Vilhardt H, Gjerris F, Warberg J. Impermeability of the blood-cerebrospinal fluid barrier to 1-deamino-8-D-arginine-vasopressin (DDAVP) in man. Eur J Clin Invest (In press).

${ }^{42}$ Gold PW, Ballenger JC, Zis AP, Robertson G, Post R, Goodwin FK. A vasopressin hypothesis of affective illness: Preliminary findings. In: Usdin E, Kopin IJ,
Borchas JD, eds. Catecholamines: Basic and Clinical Frontiers. New York: Pergamon Press, 1979:180719.

${ }^{43}$ Gold PW, Goodwin FK, Post R, Robertson GL. Vasopressin function in depression and mania. Psychopharmacol Bull 1981;17:7-9.

4 Sørensen PS, Hammer M, Bolwig TG. Vasopressin release during electroconvulsive therapy. Psychoneuroendocrinology 1982;7:303-8. 